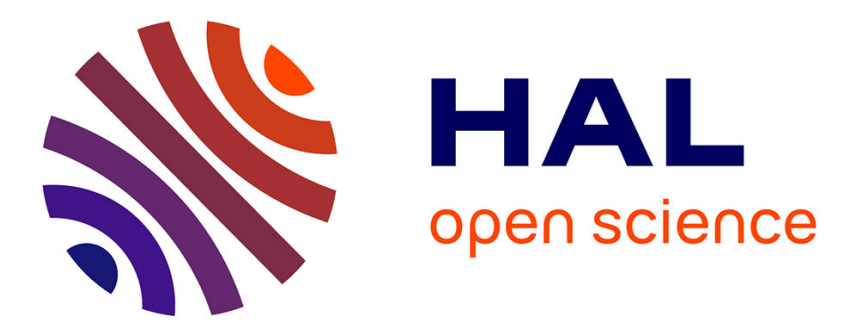

\title{
Large-scale relationships between basin and riparian land cover and the ecological status of European rivers
}

\author{
J.G. Wasson, B. Villeneuve, A. Ital, J. Murray Bligh, M. Dobiasova, S. \\ Bacikova, H. Timm, H. Pella, N. Mengin, A. Chandesris
}

\section{- To cite this version:}

J.G. Wasson, B. Villeneuve, A. Ital, J. Murray Bligh, M. Dobiasova, et al.. Large-scale relationships between basin and riparian land cover and the ecological status of European rivers. Freshwater Biology, 2010, 55, p. 1465 - p. 1482. 10.1111/j.1365-2427.2010.02443.x . hal-00538245

\section{HAL Id: hal-00538245 \\ https://hal.science/hal-00538245}

Submitted on 22 Nov 2010

HAL is a multi-disciplinary open access archive for the deposit and dissemination of scientific research documents, whether they are published or not. The documents may come from teaching and research institutions in France or abroad, or from public or private research centers.
L'archive ouverte pluridisciplinaire HAL, est destinée au dépôt et à la diffusion de documents scientifiques de niveau recherche, publiés ou non, émanant des établissements d'enseignement et de recherche français ou étrangers, des laboratoires publics ou privés. 
Large scale relationships between basin and riparian land cover and ecological status of European rivers: examples with invertebrate indices from France, Estonia, Slovakia and United Kingdom.

\author{
JEAN-GABRIEL WASSON ${ }^{1}$, BERTRAND VILLENEUVE ${ }^{1}$, ARVO ITTAL $^{2}$, JOHN $^{-}$ \\ MURRAY-BLIGH ${ }^{3}$, MARCELA DOBIASOVA $^{4}$, STANISLAVA BACIKOVA $^{4}$, HENN \\ TIMM $^{5}$, HERVÉ PELLA ${ }^{1}$, NICOLAS MENGIN ${ }^{1}$, ANDRÉ CHANDESRIS ${ }^{1}$

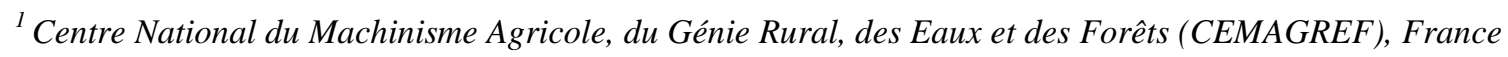 \\ ${ }^{2}$ Institute of Environmental Engineering, Tallinn University of Technology (TTU), Estonia \\ ${ }^{3}$ Environment Agency, UK \\ ${ }^{4}$ Slovak Hydrometeorological Institute (SHMI), Slovak Republic \\ ${ }^{5}$ Institute of Agricultural and Environmental Sciences, Estonian University of Life Sciences, Estonia
}

\title{
SUMMARY
}

1 - The study of large-scale pressure-impact relationships involves questions of hierarchy and scales. Answers to these questions will help managers define priorities for action to achieve the 'good ecological status' required by the Water Framework Directive (WFD). The main objectives of our study were 1) to establish the relative impact of pressures that degrade ecological status, especially those caused by agriculture and urbanization, 2) to identify regional patterns in these pressure-impact relationships and 3) to evaluate the relative weight of the pressures acting at the basin and riparian corridor scales, and the possible buffering effect of riparian areas.

2 - We developed large-scale models linking invertebrate indices of ecological quality to river basin and riparian land cover in France, Slovakia, Estonia and UK. Invertebrate indices, transformed to Ecological Quality Ratios (EQR), were taken from national monitoring networks. We based the models on Partial Least Squares (PLS) regressions at national and a hydro-ecoregion (HER) scales. The HERs provided a framework for grouping data in terms of natural river features and human activities.

3 - The different national methods provided consistent results that indicated the hierarchy of pressures impacting river invertebrates at the European scale. The most salient result was that artificial land cover (e.g. urban and industrial sites) in the river basin represented the pressure with the most negative impact on invertebrate indices, in all countries and regions. 
4 - The impact of agricultural land cover was more variable. Arable land had a smaller impact than urban areas, and it was even insignificant in some models. The impact of vineyards depended on the natural geographical context. The effect of pastures seemed to be related to the intensity of the livestock they carried. These results supported the concept of regional pathologies for river ecosystems, as land use and anthropogenic influences are closely linked to physical landscape features. The proportion of arable land in the river basin appeared to be a weak predictor of agricultural impacts by itself; the type of cultivation and intensity as well as the proximity to the river must be taken into account.

5 - At the riparian corridor scale, the negative impact of artificial areas or arable land and the positive effects of forests and pastures were demonstrated in many regions. The protective effect of riparian forests against mixed agricultural and urban pressures was demonstrated in three regions in France. Riparian corridors appear to be manageable areas, and these results strongly support the idea of including their restoration in priority actions for achieving good ecological status.

Keywords: pressure-impact models, hydro-ecoregion, riparian buffer, urbanisation, agricultural impact, streams, partial least squares regression, water framework directive.

Correspondence: Jean-Gabriel Wasson, Cemagref, UR BELY, 3 bis quai Chauveau - CP 220, F-69336 Lyon, France. E-mail: jean-gabriel.wasson@cemagref.fr

\section{Introduction}

The environmental objectives of the Water Framework Directive (WFD, 2000/60/EC), to achieve good ecological status for all water bodies in a given time horizon (Article 4), gives rise to some serious problems for political decision-makers and water managers, and many questions for aquatic scientists. Initially, most of the research for the directive was dedicated to developing of methods for evaluating ecological status (Hering et al., 2004; Furse et al., 2006; Pont et al., 2006). However, scientific support for defining programmes of measures necessary to maintain or improve the ecological status of water bodies has been rather weak. The study of the relationships between anthropogenic pressures and ecological status in stream and river ecosystems at large geographical scales involves both conceptual and 
methodological issues. The main problem is to quantify the responses of biological indicators to the whole array of impacting pressures, and to rank the causes of impacts in order of their importance. Of these, the relative influence of agriculture and urbanisation is a crucial and somewhat controversial issue (EEA, 2003; Moore \& Palmer, 2005; Burcher \& Benfield, 2006). A related issue concerns spatial scale that is appropriate for analysing these relationships: the impact of a given land use can be different at the basin level compared to close to the river at the riparian corridor level (Wang, Lyons \& Kanehl, 2001). Moreover, the buffering capacity of forested riparian corridors can mitigate the effects of pressures coming from agricultural or urban areas in the basin (Moore \& Palmer, 2005). However, the regional variability of these pressure-impact relationships has seldom been analysed at a large geographical scale. Both the spatial pattern of human activities and differences in ecological responses according to the natural characteristics of the river types could lead to distinct regional pathologies. The protective effect of riparian corridors also needs to be evaluated at large scales, in order to determine the most effective management scale (Dovciak \& Perry, 2002).

There is a clear lack of knowledge about the relationships between combined pressures and the ecological status of rivers at large scales (Allan, 2004; Garcia, Villeneuve \& Wasson, 2006). Except for the work of Donohue, McGarrigle \& Mills, (2006) in Ireland, we are not aware, within Europe, of models linking human activities (evaluated through land cover) to ecological status at a large or even a regional scale. In one of the pioneer works, Steedman, (1988) demonstrated positive relationships between the condition of the fish community and both the percentage of forest in the basin and the proportion of channel with riparian forest, and a strong negative relationship with urbanization in the catchment. He also emphasized the need for a more detailed evaluation of agricultural land use and streamside vegetation to improve predictive models. All these issues remain unresolved (Allan, 2004), even though the answers are prerequisites for defining management policies. Decision-makers must prioritize their actions and define integrated policies tailored towards socio-economical structures, such as urban and rural development zones. For practical reasons, they need to know whether the same policies must be applied everywhere or adapted to regional contexts, and whether the management of the riparian areas can be used to improve the ecological status.

In order to provide managers and decision-makers with practical recommendations, we chose to develop large-scale models, based on existing data, to give answers applicable to the decision and management scales, i.e. European, national and regional. The benthic invertebrates appeared to be the best indicators of ecological status for comparing the 
pressure-impact relationships in different European countries for two reasons: i) they respond to a wide range of pressures, including hydro-morphological degradation (Buffagni et al., 2006; Hering et al., 2006), and ii) data were available from existing national monitoring networks. Moreover, the invertebrate indices were submitted to the WFD Intercalibration process, ensuring the comparability of the evaluations of ecological status (Olsauskyke \& Van de Bund, 2008). For the statistical model, the Partial Least Square (PLS) regression was preferred because it enabled the relative effect of the factors influencing the biological response variable to be ranked (Wold, Sjöström \& Eriksson, 2001). To evaluate the stressors, land cover appeared to be the only indicator available at the European level that was able to represent the wide array of human activities that impact aquatic ecosystems (Allan \& Johnson, 1997). The basin and the riparian corridor spatial scales were analysed at each site. Finally, a map of European hydro-ecoregions (Wasson et al., 2007) was used as a framework to make regional models for evaluating geographical variability.

The main objective of our study was to compare the relationships between the combined pressures represented by the land cover, and the ecological status of running water bodies in four different European countries: France, Slovakia, Estonia, and UK (England and Wales). We developed large-scale pressure-impact models, based on PLS regressions, that related comparable benthic invertebrate indices to land cover indicators calculated at the basin and riparian corridor scales. Data from the four countries were further stratified into regional datasets according to hydro-ecoregions. The more specific objectives of the study were 1) to establish the hierarchy of the major influences that impact ecological status, particularly agriculture and urbanisation, 2) to identify regional patterns in these pressure-impact relationships and 3) to evaluate the relative weight of the pressures acting at the basin and riparian corridor scales, and the possible buffering effect of riparian land cover.

\section{Methods}

\section{Evaluation of pressure}

Ecological impacts in running waters are the result of various pressures acting simultaneously: clearly identified point sources discharges, but also more complex human influences including diffuse pollution, alteration of water and sediment regimes, artificial structures, breaks in connectivity, etc. (Borchardt \& Richter, 2003). Following the DPSIR (driving forces, pressure, state, impact, response) concept (EEA, 2003), the driving forces are human activities (e.g. agriculture, urbanization) generating a combination of pressures (pollution discharges, physical alterations...) which alter the abiotic components of the 
ecosystem (physico-chemistry, hydro-morphology). These alterations have an impact on biological communities and thus ecological status. Because of the lack of homogeneous datasets of pressures or abiotic parameters, land cover was the only useable source of spatially consistent information at the European scale to represent the driving forces.

For each biological monitoring site, land cover indicators were calculated at the basin scale. In France, Slovakia and Estonia, the CORINE Land Cover (CLC) 2000 map was used. This is a vector map, drawn from satellite imagery at a scale of 1:100 000, with a minimum polygon size of 25 ha (http://terrestrial.eionet.europa.eu/CLC2000). The CLC is based on a hierarchical standard nomenclature with 3 levels: 5 broad land cover categories at level-1 (1artificial surfaces, 2-agricultural areas, 3-forests and semi-natural areas, 4-wetlands and 5water bodies), 15 land cover classes (level-2) and 44 land cover types (level-3). The third level of CLC 2000 was used to describe the land cover in all the areas studied, except for Slovakia where only the level-1 was available at the basin scale. For UK, the land cover indicators were from the Land Cover Map (LCM) 2000 (Fuller et al., 2002). Although not identical, the LCM 2000 categories are comparable to those used in the CLC 2000 classification.

Land cover indicators for the riparian corridors were also calculated from the CLC level-3 in France, Slovakia and Estonia. The corridors were delineated by sections 3 kilometres long, $2.5 \mathrm{~km}$ upstream and $0.5 \mathrm{~km}$ downstream of each biological monitoring site. In France and Estonia, the width of the corridor was adjusted to the river width, according to the Strahler stream order: $100 \mathrm{~m}$ for the $1^{\text {st }}$ to $3^{\text {rd }}$ order streams, $140 \mathrm{~m}$ for $4^{\text {th }}$ order, $250 \mathrm{~m}$ for $5^{\text {th }}$ order, $600 \mathrm{~m}$ for order $6^{\text {th }}$ order, $1200 \mathrm{~m}$ for order $7^{\text {th }}$ order and $2400 \mathrm{~m}$ for $8^{\text {th }}$ order (Pella, Chandesris \& Wasson, 2004). In Slovakia, the width of the corridor was fixed at $100 \mathrm{~m}$ for all sites. Given the resolution of the CLC map, the riparian land cover indicators do not represent the narrow buffer strips along the river margins but only the proportion of the CLC types recognized in the delineated corridors (Tormos et al., 2006).

\section{Biological Datasets}

The invertebrate datasets were extracted from the national monitoring networks. The sampling sites were well distributed spatially, and the coverage was roughly the same for France, Slovakia and Estonia (1 site for 140 to $270 \mathrm{~km}^{2}$ of land area), but denser for UK (1 site for $33 \mathrm{~km}^{2}$ ). In Estonia, the index used was the Average Score Per Taxon (ASPT), which is based on family-level data (Armitage et al., 1983). The ASPT is a rather robust indicator able to reflect general degradation. The database provided by the Centre for Limnology 
(Institute of Agricultural and Environmental Science) comprised 168 stations with 179 samples from 1988-2004. In France, the biological stations were monitored by the Regional Environmental boards (DIREN) using the IBGN index (Indice Biologique Global Normalisé) (A.F.N.O.R., 1992). The IBGN is a combination of two metrics: the total number of taxa (14 classes at family level), and a Faunistic Indicator Group (GFI) representing the presence/absence of 39 indicator taxa, grouped into 9 classes of sensitivity. The index is sensitive to pollution (including toxics), and to general degradation (including habitat alteration). The national dataset, handled by CEMAGREF, currently comprises 3662 stations and 12682 samples covering the period 1992-2002. The mean IBGN value for each site was used in the models. In Slovakia, the Saprobic Index (SI) was used (Zelinka \& Marvan, 1986). The SI works at species-level but recognizes only those taxa to which saprobic and indicative values have been assigned. It is a sensitive indicator of organic pollution, associated oxygen regime and nutrient concentrations. The dataset provided by The Slovak Hydrometeorological Institute from the Slovakian water quality database comprised 220 stations with 226 samples from 2003. In UK, the indices used in the national classification scheme were the ASPT and the Number of Taxa (N-Taxa), based on family-level data (Hemsley-Flint, 2000). The combination of both metrics reacts to a wide array of pressures. The RIVPACS model (Wright, Sutcliffe \& Furse, 2000) was used to predict the reference values of the two indices. The Ecological Quality Index (EQI) for ASPT and N-Taxa at each site was calculated using observed values of each index and the expected values obtained from RIVPACS. The database provided by the Environment Agency comprised 4508 stations and results (as EQIASPT and EQI N-Taxa) from 4508 composite 'spring + autumn' RIVPACS samples collected in 1995.

The WFD requires ecological status to be evaluated as an Ecological Quality Ratio (EQR), i.e. a deviation from reference conditions. In Estonia, France and Slovakia, the indices were transformed to EQR values by dividing the observed values by reference values for each national river type. The reference values were derived from data observed at reference sites. The criteria used for the selection of reference sites in these countries complied with the criteria agreed in the WFD Intercalibration process (REFCOND, 2003), and the EQR values were equivalent to those used at the national level for determining the WFD ecological status. For UK, EQI values were used instead of EQRs. The biological quality of RIVPACS reference sites was the best available, which was sometimes poorer than the WFD reference state, particularly in lowlands. As a consequence, RIVPACS EQIs need adjustment to convert them to EQR values that meet the WFD's requirements (Davy-Bowker et al., 2008). For UK 
therefore, EQRs in lowland England will indicate poorer quality than the EQIs used in this study.

\section{Hydro-ecoregion framework}

Ecoregions have been adapted to aquatic ecosystems by Omernik (1987) in order to define regional objectives for water quality and management (Hughes \& Larsen, 1988; Warry \& Hanau, 1993), and they are still widely used in the USA (Omernik, 2004). But in Europe, the 'WFD ecoregion' map from Illies (1978) has many weaknesses because it reflects biogeography more than river functioning (Verdonschot \& Nijboer, 2004). The hydroecoregions (HER) are based on a top-down approach, allowing an a priori delimitation of geographical entities in which stream and river ecosystems should exhibit common characteristics. Geology, relief and climate are widely recognized as the primary large-scale determinants of running-water ecosystem functioning (Naiman et al., 1992), and HERs are delimited on the basis of these factors (Wasson, 1996; Wasson et al., 2002a; Wasson et al., 2002c). This method was used in France to define the national WFD river typology (Wasson et al., 2002b). The rationale and a description of the European HERs can be found in Wasson et al. (2007). The HER map was used to stratify both river types and human activities in this study.

\section{Study areas}

In the present work, we developed models at both the country level and for HERs or groups of HERs with similar characteristics (Fig. 1 and Table 1). The main land cover characteristics of these regions are summarized in Table 2.

In France, sites were stratified into 4 regions representative of the geographical diversity and covering 55\% of the country. The Armorican region corresponds to Hercynian shield lowlands; most of the urban areas are located along the coasts, and the agriculture, described as 'complex cultivation patterns', is mainly intensive animal husbandry, with a high density of animals (>1.25 Livestock Units per hectare of catchment). The Tables Calcaires region covers $25 \%$ of France; the landscape comprises lowlands and plains, with low energy rivers. The land cover is characterized by the strong contrast between the densely urbanized areas around Paris and the depopulated rural areas, by extensive agricultural land cover mainly dedicated to crops (corn, maize), to pastures near the Channel coast (Normandy), and locally to vineyards (Champagne). The Massif Central is a granitic region of hills and mid-altitude mountains, where the land cover is mainly pasture, forest and semi-natural areas; the population density is 
well below the national average, but there are some important industrial and urban concentrations in the main valleys. In the Mediterranean region, urbanisation has developed along the coast and in the plains, with a high tourist pressure in summer. The vineyards and orchards in the Rhône valley and coastal plains are surrounded by extensive hilly landscapes covered by forests and natural vegetation.

Slovakia was divided into two regions. The Carpathians, with tertiary mountains reaching $1500 \mathrm{~m}$ and mostly covered by forests, represents most of the country. Human settlements are scattered along small and middle-sized rivers. The remaining territory corresponds to the Pannonians, plains and lowlands bordered by hilly landscapes with densely populated fertile lands and large rivers. The main sources of organic pollution and nutrients are municipal waste waters, agriculture and reservoirs.

Estonia was included in only one HER, the Baltic plain, composed of moraine overlying limestone and sandstone and with a relatively cold climate. Most rivers are rather short with a low slope. More than half the country is covered by woodland and natural areas, and a third is used for agriculture, including pastures. Wetlands (reeds, fens and bogs) and water bodies cover $10 \%$ of the country, but woodlands also include swampy forests, floodplains and bog pine forests. Urban and industrial areas, concentrated mainly in the North and North-East of the country (Meiner, 1999), cover 2\% of the country. Many rivers were modified in 1950s1970s by deepening and damming.

The UK was stratified into 4 regions. The first two correspond to hilly landscapes under an Atlantic climate: the English Uplands with a complex geology made of limestone bedrock overlain by base-poor millstone grit deposited during the last glaciation, and Cornwall and Wales with granitic and metamorphic bedrock. In both regions, most of the landscape is covered by pastures and semi-natural vegetation, but urbanisation is common in valleys in the English Uplands. The two lowland regions with temperate climates are separated by the dominant geology: pre-cretaceous sedimentary rocks for the English Sedimentary, and the characteristic English Chalk with areas of clay. Both regions have a very high coverage of urban and arable land, but pastures are also important in the former.

\section{Statistical models}

We used the Partial Least Square (PLS) regression to model the influence of land cover (CLC types) on the invertebrate indices (EQR or EQI values). PLS regression is an extension of multiple linear regression (MLR) (Höskuldsson, 1988; Tenenhaus, Gauchi \& Menardo, 1995; Tenenhaus, 1998; Wold, 1966; Wold, 1982; Wold et al., 2001). The regression problem, i.e. 
how to model one dependent variable (Y) by the mean of a set of predictor variables $(\mathrm{X})$ is one of the most common problems in data analysis. Traditionally, this is done by using MLR, which works well as long as the X-variables are relatively few and fairly uncorrelated. By handling numerous and co-linear X-variables, PLS regression allows us to investigate more complex problems than MLR and to analyze all the available data in a more realistic way (Wold et al., 2001). The objective of PLS is to compensate for the main defect of MLR: the instability of the regression coefficients caused by the co-linearity of the predictors. Indeed, when the co-linearity is strong between the predictive $\mathrm{X}$-variables (strong correlations, large number of predictors, etc.), the estimates of the regression coefficients fluctuate greatly from one sample to another (Cramer et al., 1988) and their interpretation becomes hazardous. In such cases, the MLR coefficients are misleading and un-interpretable. When the correlation between the X-variables is high, MLR cannot assign 'correct' values to the individual coefficients, but only estimate their joint contribution to Y (Wold et al., 2001). In PLS regression, the coefficients of the predictors can be interpreted as degrees of correlation between each predictor and the dependent variable, even when there is a strong correlation between the predictors. These coefficients are comparable (in sign and amplitude) to those of a simple correlation (Tenenhaus et al., 1995; Wold et al., 2001).

The NIPALS algorithm implemented in XLStat 2006 software (AddinSoft, France) examines both $\mathrm{X}$ and $\mathrm{Y}$ and extracts components that are directly relevant to both sets of variables. These are extracted in decreasing order of relevance. The number of components to be retained is then determined by cross validation according to an error minimisation criterion, the Prediction Error Sum of Squares (PRESS), which corresponds to the sum of all the prediction error squares calculated from the test sets. This gives a regression equation that is comparable to the equation of the conventional linear regression model. To evaluate the degree of relationship between each predictor and the response variable, we interpreted only the standardized PLS coefficients as giving the relative weights of the different predictors in the models.

Jack-knifing (Efron \& Gong, 1983) is a convenient way to estimate the standard errors and confidence intervals of the coefficients, directly from the data.. Wold (1982) recommended this in his original PLS work, and it has been revived by Martens \& Martens (2000) and others. The idea is simple. The variation in the parameters of the various sub-models obtained during cross-validation of the PLS model is used to derive their standard deviations, and then the t-distribution is used to give confidence intervals. Since all PLS parameters are linear combinations of the original data, these parameters are close to being normally distributed, 
and hence jack-knifing works well. We used a 95\% confidence interval. PLS coefficients are significant at the $5 \%$ level when the confidence interval does not cover zero. Only those land cover categories that had a significant relationship with the biological indices according to the jack-knife test were retained in the models.

The presence of different impacting land cover categories in the basins, such as urban and agricultural, can blur the relationships and make them difficult to interpret (Meador \& Goldstein, 2003). In order to discriminate the relative impact of these two major driving forces better, we tested the effect of agricultural land cover independently of its correlation with the percentage of urban land cover in the basins. For each region, we analysed the Pearson correlation between these two land cover categories. First we produced a linear regression to explain the EQR (or EQI) by the percentage of urban land cover in the basins. Then, we made a multiple linear regression (classical MLR) with the percentage of agricultural land cover added as a second predictor, in order to evaluate the part of the EQR variation caused by agriculture. Urban land cover was considered to be the whole CORINE artificial surfaces category (CLC 1) in Estonia, France and Slovakia, and the sum of Land Cover 2000 urban and suburban land cover categories (LCM $171+172)$ in UK. Agricultural land cover was evaluated as arable land for Estonia, France (CLC 211) and UK (LCM 4), and as the whole agricultural category for Slovakia (CLC 2). The urban and agricultural models were compared using an extra sum of square F-test (Sokal and Rohlf, 1995).

Finally, in three French regions, we tested the effect of the presence of potentially protective land cover, pastures (CLC 231) and forests (CLC 311 and 312), in the riparian corridors. We regressed EQR-IBGN against the proportion of these land cover types in the corridors, and we reported the slope (and its confidence interval) for that regressions. The slope is significant when the confidence interval does not cover zero. The model was run for subsets of sites having predominantly agricultural or mixed (urban and agricultural) pressures in their catchments: agricultural basins had $<2 \%$ of artificial areas (CLC 1) and $>30 \%$ of cultivation (CLC 211, 221, 222, 241, and 242); mixed pressure basins had $>2 \%$ of urban areas and < $80 \%$ of cultivation.

All statistical analyses were undertaken with XLStat 2006 software (AddinSoft, France).

\section{Results}

Land cover effect at the basin and riparian scale

France. The coefficient of determination $\left(\mathrm{R}^{2}\right)$ of the PLS regression models was $18 \%$ at the national level, but at the regional scale the models had lower $\mathrm{R}^{2}$ in the lowland regions 
(Tables Calcaires, 15\%; Armorican, 20\%) than in the mountains (Massif Central, 31\%), with the highest value in the Mediterranean region (38\%) (Table 3). There was a clear distinction between the CLC categories showing a negative relationship with the EQR-IBGN and those with a positive relationship. The artificial areas, particularly continuous urban areas, discontinuous urban areas, and industrial-commercial units (CLC-111, 112 and 121) had a clear and strong negative effect at both the basin and riparian scales, at the national level and in the four regions tested. The effect of dump and construction sites appeared only at the national level. Among the agricultural areas, a distinction must be made between the arable land, vineyards and fruit trees (CLC 211, 221 and 222) which had a negative effect, and the pastures (CLC 231) which had a positive effect. The negative effects of arable land, vineyards and fruit trees at the national level were about half those of the artificial areas. Arable land had a negative effect at both the basin and riparian scales at the national level, but at the regional level it was significant only in the Armorican model. Vineyards had a clear negative effect at the national level, but this effect appeared only in the Massif Central and Armorican regions. Fruit trees had a strong negative effect in the Mediterranean region, and a weaker one in the Armorican region. The positive effect of pastures was evident only in the Tables Calcaires and Mediterranean regions, at both the basin and riparian scales. All the categories of forests and semi-natural areas exhibited positive relationships. The positive effect of forests (CLC 311, 312, 313) was clear, at both the basin and riparian scales, at the national level and in all regions except the Tables Calcaires. Other semi-natural land cover categories (CLC 322, 333) appeared only in some models (national and Mediterranean).

Slovakia. The $\mathrm{R}^{2}$ of the models was greatest at the national level (44\%), and indicated better relationships in the mountains (Carpathians 38\%) than in the lowlands (Pannonians 29\%) (Table 4). At the basin level, artificial surfaces (CLC 1) and agricultural areas (CLC 2) had a clear negative relationship with the EQR-SI; both categories had a similar effect at the national level and in the mountains, but in the lowlands the relative effect of the artificial surfaces was much greater. Forests and semi-natural areas had a similar positive effect. At the riparian level, in the national model, industrial and commercial areas (CLC 121) and arable land (CLC 211) had a negative effect, while all forest categories had a positive effect. However, the regional patterns were clearly different: the same CLC categories appeared with comparable weights in the Carpathians, while in the Pannonians, only the broad-leaved forest had a significant positive effect.

Estonia. The $\mathrm{R}^{2}$ of the national model was $39 \%$ (Table 5). Discontinuous urban areas together with industrial and commercials units (CLC 112 and 121) had the highest negative 
relationships with the EQR-ASPT at the basin level, with a significant riparian effect for the first category (CLC 112). The regression coefficient for arable land (CLC 211) was half of that of the artificial areas (CLC 112 and 121). Among the natural land cover categories, we observed positive relationships for mixed forest (CLC 313) and water bodies (CLC 512) in the basins, and coniferous forest (CLC 312) in the riparian corridor, but natural grassland had an unexpected negative regression coefficient.

UK. Models were developed with basin scale LCM indicators for N-Taxa and ASPT expressed as EQIs. As a whole, the results for both indices were very similar. The $\mathrm{R}^{2}$ was generally higher for ASPT, but the patterns and relative weights of the variables entering the models were identical (Table 6). Urban and suburban-rural developed land cover (LCM 172 and 171) always had by far the greatest negative effects. Two agricultural land cover categories appeared only in the English Sedimentary model, but surprisingly as a positive factor for arable land (LCM 4) and negative for neutral grass (LCM 61). In all other models, the improved grassland (LCM 51) had a positive relationship, as did acid grass (LCM 81) in the English Uplands region. The natural and semi-natural areas, including broad leaved and coniferous woodland (LCM 11 and 21) together with bracken (LCM 91) and heath (LCM 10), generally had positive effects in the national and regional models. Broad-leaved woodland was a notable exception, appearing as a negative factor in the English Uplands. These natural areas had no significant effects in the two regions Cornwall and Wales and English Chalk. All the regional models differed with regard to the effects of agricultural and natural areas.

\section{Urban vs. agricultural effect}

As a whole, the negative effect of artificial land cover was predominant in all the models, but some relationships for the agricultural land cover categories were unexpected. The correlation between the occurrence of urban and agricultural land cover within the basins could be different in the different regions tested, with a subsequent confounding effect in the models.

The correlation between urban areas and agricultural land cover was weak (|Pearson's $r \mid \leq 0.1$ ) in the four French regions, in the upland regions in UK, and in Estonia (Table 7). In Slovakia, the correlations were strongly positive $(r=0.53$ and 0.56$)$; conversely, in the two English lowland regions, the correlations were strongly negative $(r=-0.54$ and -0.74$)$. Some other land cover categories were positively associated with urban areas, such as broad-leaved forest in the English Uplands $(r=0.30)$, neutral grass in the English Sedimentary region $(r=0.19)$ in $\mathrm{UK}$, and fruit trees in the Mediterranean region $(\mathrm{r}=0.44)$. 
To better analyse the relative effect of urban and agricultural land cover, we ran an initial linear regression between the invertebrate indices and the urban land cover in the basins, and a second multiple linear regression between the same indices and the urban + agricultural land cover. In all the regions, the regressions with urban areas had $\mathrm{R}^{2}$ between $12.7 \%$ and $37.7 \%$ (Table 7); the highest $\mathrm{R}^{2}$ were encountered in the Mediterranean, Pannonians, English Uplands and English Sedimentary regions. In the second regression, with urban + agricultural land cover as predictors, the $\mathrm{R}^{2}$ were similar or only slightly higher. The addition of agricultural land cover as predictor increased the $\mathrm{R}^{2}$ noticeably, by between $4.5 \%$ and $8.7 \%$, in only in 3 of the 11 regions tested (Carpathians, Estonia and English Chalk).

\section{Test of a protective riparian effect}

In all the models that included the riparian scale (France, Slovakia and Estonia), the presence of pastures or forests in the river corridors had a significant positive effect on the invertebrate indices (Tables 3, $4 \& 5$ ). This could be interpreted as a protective effect of these land cover categories against pressures coming from arable land or artificial areas at the basin scale (Moore \& Palmer, 2005). To validate this hypothesis, we tested the effects that could be related to the presence in the riparian corridor of pastures and forests, alone or combined, in three French regions (Armorican, Tables Calcaires and Massif Central). In each region, two datasets were selected that corresponded at the basin scale to a dominant agricultural pressure or to mixed pressures (agricultural and urban). In each dataset, a regression was done between the EQR-IBGN and the proportion of the supposed protective land cover in the riparian corridors. All the significant relationships indicated a positive effect on the EQR-IBGN (Tables 8, 9 and 10).

The presence of pastures alone (CLC 231) in the riparian corridors had a significant effect in the mixed pressures basins of the Massif Central and Tables Calcaires, but not in the Armorican region (Table 8). Broad-leaved forests alone (CLC 311) had a significant effect in the mixed pressure basins of the Armorican region (Table 9), but not in the Tables Calcaires or the Massif Central. Broad leaved forests also had a significant effect in the agricultural basins in the Massif Central, and coniferous forests (CLC 312) had a strong effect in the mixed pressures basins in the Massif Central. The combination of pastures and forests in the riparian corridors (Table 10) had a significant effect in the agricultural basins of the Tables Calcaires; in the mixed pressures basins, the effect was significant in both the Tables 
The slope of the regression indicated the change in EQR-IBGN for a given change in the proportion of a particular type of land cover (Tables 8, 9 and 10). The greater the slope, the greater the effect on EQR-IBGN. For example, a significant slope of 0.3 indicated that an increase of 0.5 in the proportion of the protective land cover in the riparian corridors could lead to a corresponding increase of 0.15 of the EQR-IBGN $(0.3 \times 0.5=0.15)$.

\section{Discussion}

\section{Invertebrate indices responses}

As whole, the invertebrate indices used in the four countries gave consistent results and responded with similar patterns to the land cover indicators. The UK and French methods, which both use a sensitivity index (ASPT or GFI) and the number of families, are conceptually similar. The fact that the two metrics used in UK (ASPT and N-Taxa) behaved similarly enables a good comparison with Estonian data, which was based only on ASPT. Although based on a different concept, the Saprobic index used in Slovakia did not give contradictory results. The transformation of the French, Slovakian and Estonian indices to type-specific EQR values, conceptually close to the site-specific EQI used in UK, provided a good comparability of the models across countries and regions.

In all countries, some models accounted for $\mathrm{R}^{2}$ around $40 \%$. Such $\mathrm{R}^{2}$ values can be considered to reflect good relationships considering 1) the distance, in terms of ecological processes, between the land cover indicators evaluated from satellite imagery and the biological response evaluated through a synthetic index, 2) the noise associated with monitoring data collected by different laboratories and sometimes covering different years, and 3) the fact that only a part of the variability of the predictors is retained in the PLS regression. Consequently, lower $\mathrm{R}^{2}$ can be interpreted as weaker relationships in the models. In this case, two explanations are possible: either the land cover indicators do not represent the actual pressures acting in the region well, or the invertebrate index does not react in the same way to the pressures. In France and Slovakia, the regional models had higher $\mathrm{R}^{2}$ in mountains than in lowlands. However, in the lowlands of Estonia, the model was good, and in UK, only the Cornwall and Wales model had a low $\mathrm{R}^{2}$. Thus, both explanations are plausible but the hypothesis that the French and Slovakian invertebrates indices are less sensitive in the lowland rivers cannot be ignored. Whether these different responses reflect a true difference in the sensitivity of ecosystems to pressures remains an open question. For this reason, we shall interpret only the relative weights of the factors in the different models. 


\section{Hierarchy of impacts: urbanization vs. agriculture}

The relative impact of agriculture and urbanization on aquatic biota is not well established. Various studies have demonstrated negative relationships between biological indices and the percentage of agricultural land in the catchment or gradients of agricultural intensity (Roth, Allan \& Erickson, 1996; Walser \& Bart, 1999; Cuffney et al., 2000). These impacts are dependent on the different categories of production: many authors designate intensive agriculture as a cause of degradation in stream habitats (Allan \& Johnson, 1997; Allan, 2004). Moreover, physical alterations caused by agriculture can generate biological impacts over decades (Harding et al., 1998). Other authors have found less negative effects (Meador \& Goldstein, 2003), or even positive relationships between agricultural land cover and invertebrate diversity (Moore \& Palmer, 2005). The impacts of urbanisation are mainly related to the direct effects of point sources of pollution. However, many other pressures are generated by urban areas, such as canalization, untreated storm-water and altered hydrological regimes (Cormier et al., 2000), and these cause both hydro-morphological and biological impacts (Paul \& Meyer, 2001; Stepenuck, Crunkilton \& Wang, 2002; Roy et al., 2003; Wang \& Kanehl, 2003). When comparing the impacts of different forms of land cover, some authors found agriculture to be the most damaging activity, while others found the strongest negative correlations with urban areas. The hierarchy of relationships between these driving forces may vary according to the human or ecoregional context, although some of the differences observed could have been caused by the methodology (bioindicators, models, scales). Our results show that in 12 of the 14 PLS models, urban or artificial land cover (sensu CORINE nomenclature) appeared to be by far the most important negative factor on invertebrates indices at the national and regional scales. Artificial and agricultural areas had a similar weight only in Slovakia at the national level and in the Carpathians at the regional level. For the national models, the effect of the urban areas was about twice that of the impacting agricultural land cover categories in France and Estonia, and in UK agriculture appeared to have no negative effect. This picture was validated and even strengthened by the direct linear regressions (Table 7), correcting a possible confounding effect introduced by the correlation between the percentage of urban and agricultural land cover within the basins. For instance, in the Carpathians, the apparently stronger negative effect of agriculture could be caused by a positive correlation between urban and agricultural land cover: cultivated basins are also more impacted by urbanization. The null or very low increase in $\mathrm{R}^{2}$ when adding the agricultural land cover as a predictor in the linear regressions demonstrated that, in all cases, the effect of urban areas was much stronger than the effect of arable land. In the Carpathians, 
for instance, the urban effect was 3 times greater than the effect of agricultural land cover, and in the English lowlands the effect of arable land was null or very low.

Urban areas had a strong negative impact in all the regions analysed. On the other hand, forests and semi-natural land cover (such as moors and heathland, bracken, and transitional scrub...) appeared to be positive influences (with one exception in UK). However, the effect of agricultural land cover, including arable land, pastures and some semi-natural grassland, was much more variable. Seen from the largest scale, the national level, agricultural areas, and particularly arable lands, had a negative effect, except in UK. In general, the intensity of this impact remained moderate, but it is a potential concern in extensive areas of Europe. However, the regional patterns were very different and deserve a more detailed analysis in order to identify the relative impacts of different agricultural land covers better, especially between arable land and pastures.

\section{Regional variability of agricultural impacts}

Because of the "covariation of anthropogenic and natural landscape features" (Allan, 2004), natural constraints (e.g. terrain slope, rainfall regime) could determine the sensitivity of the ecosystems, as well as the land use practices, leading to different regional responses. In testing the effectiveness of two landscape classifications (watershed vs. agro-ecoregion), Dovciak \& Perry (2002) observed that local habitat conditions, which strongly influence invertebrate assemblages, were determined by regional-scale landscape factors. In order to understand ecological relationships better and to help decision-making, a regional approach could be useful to identify regional river 'pathologies' that should be managed differently, even within a country.

In Slovakia, the data available did not allow the effects of arable land and pastures to be separated at the basin scale. However, both PLS models and linear regressions demonstrated that the impact of agricultural areas was greater in the mountains than in the lowlands. In Estonia, both arable lands and natural grasslands had a similar negative effect. The latter are used as pastures, usually with the clear-cutting of the whole riparian corridor that leads to intensive growth of macrophytes in low gradient rivers, with accumulation of mud that could explain the changes in the fauna. In UK, we observed three different regional patterns. In the English Uplands, the categories of open land used as pastures had a positive effect; this was expected for Bracken (Pteridium aquilinum) supporting a very low intensity sheep-farming, but the more intensive agriculture for dairy and livestock generally associated with improved grassland did not produce a negative effect. The unexpected negative PLS coefficient for 
broad-leaved woodland was explained by a positive correlation between deciduous forests and urbanisation (including historical industrialisation) in the lowest parts of the Pennine valleys; thus, this relationship cannot be interpreted as an impact. In the English Sedimentary PLS model, forests had the expected positive effect, but neutral grass had a negative coefficient. Despite a weak correlation between neutral grass and urbanisation, this result could correspond to a true ecological impact, as water pollution from farm wastes was recognized as a significant problem in the 1990s (Skinner et al., 1997). The positive effect of arable land in this region was a surprising result, explained by a strong negative correlation between the proportion of urban areas and arable land within the basins: so, the most agricultural basins are much less impacted by urban pressures. This was corroborated by the null effect of arable land in the direct linear regression (Table 7). Similarly, Wang et al. (2000) observed a positive correlation between agricultural land use and fish biotic integrity in Wisconsin, where high levels of agriculture were associated with low level of urbanization. Therefore, we cannot demonstrate any impact on invertebrate indices related to the percentage of arable land in the basins of this English Sedimentary region.

In France also, the regional models showed different patterns in the impacts of agricultural land cover. The high impact of vineyards was demonstrated only in the Massif Central and in the Armorican regions, because of some localized vineyards, but not in the Mediterranean region even though vineyards are encountered in half of its basins. Here, the natural characteristics of the HERs could probably explain the difference in the regional responses. The siliceous bedrock and the flow regimes could lead to a greater transfer of sediment and pesticides in the Armorican and Massif Central vineyards than in the Mediterranean ones, and so to a stronger biological impact. Pastures had a positive effect in the Mediterranean region with low intensity sheep farming, and in the Tables Calcaires, but pastures did not appear in the PLS models of the two regions most dedicated to cattle rearing: the Massif Central and Armorican. This can be interpreted as a decrease in the positive effect of pastures as the cattle breeding intensity increased.

More surprisingly, arable land appeared to have no effect in the French regional PLS models, even in the Tables Calcaires region where most basins are largely dedicated to crops. This was confirmed by the very small effect of arable land in the linear regression $\left(\mathrm{dR}^{2}=1.5 \%\right.$, Table 7). In fact, a wide range of WFD ecological status conditions, from high to bad, can be encountered in basins with a high proportion of arable land (up to 80\%) and low urbanization, but on average, the EQR-IBGN values were between the good and moderate status. Thus, in France, the results seemed contradictory: arable land had a negative effect at the national 
level, but this effect disappeared at the regional scale. This could be interpreted in the following way: in general, cultivated lowland regions have more degraded ecological conditions, but in these regions, the impact of agricultural activities is not directly linked to the percentage of arable land in the basins. In other words, the land cover alone is only a general descriptor of the probability of agricultural impacts. In cultivated areas, local factors such as natural characteristics (hill slopes, soil properties), the intensity of agricultural practices, and physical alterations to the landscape generated by agricultural development determine the actual impact on running water ecosystems (Meador \& Goldstein, 2003). Among these factors, the land use in the riparian areas is expected to exert a strong influence.

\section{Basin vs. riparian scales}

Although many papers address the issue of scaling processes and relationships, the influence of pressures acting at the riparian corridor and basin scales needs better understanding (Allan, 2004). Gergel et al. (2002) concluded from a literature review that "a variety of investigators have tried to determine the spatial extent, or distance from the water body, over which landscape patterns influence water quality or aquatic biota, yet this question remains unresolved". Some studies identify landscape-level factors as the main variables for predicting biological indicators, while others find no relationships beyond the riparian or local scale (Garcia et al., 2006). Meador \& Goldstein (2003) emphasized "the universal importance of riparian zones to the maintenance and restoration of diverse fish communities in streams", and the restoration of river corridors is seen as a key action to improve ecological conditions (Naiman, Décamps \& McClain, 2005; Palmer et al., 2005; Walsh et al., 2007). Recently, Johnson et al. (2007) proposed a model taking into account the spatial pattern of land cover

\section{within catchments to explain the biological response and develop riparian restoration}

\section{strategies.}

The actual influence of riparian areas on river biota, and particularly the invertebrate indices, has been evaluated mainly in meso-scale studies (Lammert \& Allan, 1999; Sponseller, Benfield \& Valett, 2001; Stewart et al., 2001). The PLS models used in France, Slovakia and Estonia demonstrated, at large scale, a very clear negative relationship between artificial land cover in the riparian corridors and invertebrate indices. In all the models (except in the Pannonians) discontinuous urban fabric and industrial-commercial units appeared as negative factors. In a study in France, Wasson et al. (2005) showed that the chemical indicators of domestic pollution correlated with the percentage of urban land cover in the basins, but not in the riparian corridors. Thus, the causes of impacts from artificial land cover in river corridors 
must be sought in physical alterations and diffuse contamination generated by the presence of urban and industrial areas close to the rivers, rather than in the effects of domestic pollution. Arable land cover in the riparian corridor was an important negative factor at the national level in France and in Slovakia, but not in Estonia. At the regional level, this category appeared only in the Carpathian model. Vineyards had negative impacts in the Massif Central and fruit trees in the Armorican region. In general, the presence of cultivation in the riparian corridors correlated with a biological impairment in the rivers, but the actual impact depended on local conditions. Among these, the presence of narrow vegetated buffer strips, not detected by CORINE Land Cover, could alter the relationship.

Another important result was the demonstration of the widespread positive effects of forests and pastures in the riparian corridor, shown in all the models at the national and regional scales. This result could correspond to a direct positive influence on the aquatic invertebrates, but also to a buffer effect that mitigated the negative impacts of arable land or artificial areas outside the riparian corridor. In this respect, forests and pastures must be considered separately.

The direct influence of riparian forest on invertebrate community structure is widely recognized (Maridet et al., 1998; Naiman et al., 2005), but it is not often evaluated in terms of ecological status. In our results, the effect of riparian forests, when significant, was always associated with an increase in the values of invertebrate indices. The buffer effect was tested in three French regions, in basins with either a dominant agricultural pressure or mixed urban and agricultural pressures. The presence of broad leaved forests in the riparian areas, alone or combined with pastures, had a clear positive effect in five of the six datasets tested: the mixed basins of the Armorican region, and both agricultural and mixed basins of the Tables

\section{Calcaires and Massif Central (Table 9 and 10). In most cases, the increase in EQR-IBGN}

could be sufficient to shift from the WFD moderate class to good status. In the Armorican and Massif Central regions, the positive effect of broad leaved or coniferous riparian forests was more pronounced in the mixed pressure basins than in the agricultural ones, suggesting that it was effective against urban pressures. This is consistent with the results of Moore \& Palmer (2005), but contrary to the findings of Walsh et al. (2007), who stated that in Australian urban catchments, "riparian revegetation is unlikely to have an effect on indicators of stream biological integrity". However, the effect of riparian forests was also subject to some regional variability, as it appeared weaker in the Tables Calcaires. Nevertheless, in general, riparian forests can be very effective for mitigating the impacts from both agricultural and urban land cover at the basin level. 
Evaluating the buffering effect of pastures is more complex, because they can be either a buffer intercepting fine sediments, phosphorus and pesticides coming from cropland, or a pressure generating organic and nutrients loads, and erosion from cattle trampling when they support intensive livestock. The direct effect of riparian pasture on river invertebrate communities is probably related to changes in the trophic structure caused by increased light availability, as in other open agricultural areas. In the Armorican region, dedicated to

\section{intensive animal husbandry, the effect of pastures alone in the riparian corridor was not} apparent (Table 8). The same occurred in the agricultural basins of the Massif Central, where cattle rearing, although less intensive, is also a dominant activity. But in the Massif Central, riparian pasture had a positive effect in mixed pressure basins. These facts suggest that the actual use of the riparian pastures, particularly the intensity of the livestock that they support, must always be taken into account when evaluating their ecological effect. Conversely, in the Tables Calcaires region mainly dedicated to crops, the effect of pastures was positive in the mixed basins, and the combination of pastures and woodland was very effective against pressures coming from arable land (Table 10).

These results support the conclusion that the appropriate management of riparian corridors, mixing wooded areas and extensive pastures, in agricultural as well as in urban catchments, "may have significant impact on ecosystem health" (Naiman et al., 2005). While the basin land cover is unlikely to change in the near future, riparian corridors are more manageable areas and their restoration can be an effective way to improve the ecological status of European rivers.

\section{Acknowledgments}

This work was funded by the EC $6^{\text {th }}$ Framework programme REBECCA project (WP4: Rivers) - Contract number SSPI-CT-2003-502158 - and the collaborating organisations. We thank the French Ministère de l'Écologie, du Développement et de l'Aménagement durables for special funding for this research. We are indebted to the French Regional Environmental boards (DIREN), the UK Environment Agency, the Slovakian Hydrological and Meteorological Institute and the Estonian Centre for Limnology (Institute of Agricultural and Environmental Science) for providing data. The delineation of catchments and the quantification of land cover types in Estonia were carried out by the Estonian Environment Information Centre. We have appreciated the pertinent and constructive comments provided by the anonymous reviewers. 


\section{References}

A.F.N.O.R. (1992) Essai des eaux. Détermination de l'Indice Biologique Global Normalisé (IBGN). Association Française de Normalisation - norme homologuée T 90-350, 1-8.

Allan J. D. (2004) Landscapes and riverscapes: the influence of land use on stream ecosystems. Annual Review of Ecology, Evolution and Systematics, 35, 257-284.

Allan J. D. \& Johnson L. B. (1997) Catchment-scale analysis of aquatic ecosystems. Freshwater Biology, 37, 107-111.

Armitage P. D., Moss D., Wright J. F. \& Furse M. T. (1983) The performance of a new biological water quality score system based on macro-invertebrates over a wide range of unpolluted running-water sites. Water Research, 17, 333-347.

Borchardt D. \& Richter S. (2003) Identification of significant pressures and impacts upon receiving waters. Water Science and Technology, 48, 33-38.

Buffagni A., Erba S., Cazzola M., Murray-Bligh J., Soszka H. \& Genoni P. (2006) The STAR common metrics approach to the WFD intercalibration process: Full application for small, lowland rivers in three European countries. Hydrobiologia, 566, 379-399.

Burcher C. L. \& Benfield E. F. (2006) Physical and biological responses of streams to suburbanization of historically agricultural watersheds. Journal of the North American Benthological Society, 25, 356-369.

Cormier S. M., Smith M., Norton S. \& Neiheisel T. (2000) Assessing ecological risk in watersheds: A case study of problem formulation in the Big Darby Creek watershed, Ohio, USA. Environmental Toxicology and Chemistry, 19, 1082-1096.

Cramer R. D., Bunce J. D., Patterson D. E. \& Frank I. E. (1988) Crossvalidation, bootstrapping, and partial least squares compared with multiple regression in conventional QSAR studies. Quantitative Structure-Activity Relationships, 7, 18-25.

Cuffney T. F., Meador M. R., Porter S. D. \& Gurtz M. E. (2000) Responses of physical, chemical, and biological indicators of water quality to a gradient of agricultural land use in the Yakima River Basin, Washington. Environmental Monitoring and Assessment, 64, 259-270.

Davy-Bowker J, Clarke R, Corbin T., Vincent H, Pretty J., Hawczak A., Blackburn J. , Murphy J. \& Jones I. (2008) River Invertebrate classification Tool. Final report Project WFD72c. Edinburgh: SNIFFER.

Donohue I., McGarrigle M. L. \& Mills P. (2006) Linking catchment characteristics and water chemistry with the ecological status of Irish rivers. Water Research, 40, 91-98. 
Dovciak A. L. \& Perry J. A. (2002) In search of effective scales for stream management: does agroecoregion, watershed, or their intersection best explain the variance in stream macroinvertebrate communities? Environmental Management, 30, 365-377.

EEA. (2003) Europe's water: an indicator-based assessment. Luxembourg: Office for Official Publications of the European Communities.

Efron B. \& Gong G. (1983) A leisurely look at the bootstrap, the jackknife, and crossvalidation. The American Statistician, 37, 36-48.

Fuller R. M., Smith G. M., Sanderson J. M. \& Thomson A. G. (2002) The UK Land Cover Map 2000: construction of a parcel-based vector map from satellite images. Cartographic Journal., 39, 15-25.

Furse M. T., Hering D., Brabek K., Buffagni A., Sandin L. \& Verdonschot P. F. M. (ed.) (2006) The ecological status of European rivers: evaluation and intercalibration of assessment methods. Developments in Hydrobiology 188 (reprinted from Hydrobiologia 566).

Garcia A., Villeneuve B. \& Wasson J. G. (2006) Large scale evaluations of pressures. In Indicators and methods for Water Framework Directive ecological status assessment. Linkages between chemical and biological quality of surface waters (ed. A. S. Heiskanen, A. G. Solimini \& A. C. Cardoso), pp. 213-224: REBECCA project, European Commission.

Gergel S. E., Turner M. G., Miller J. R., Melack J. M. \& Stanley E. H. (2002) Landscape indicators of human impacts to riverine systems. Aquatic Sciences, 64, 118-128.

Harding J. S., Benfield E. F., Bolstad P. V., Helfman G. S. \& Jones E. B. D. (1998) Stream biodiversity: the ghost of land use past. Proceedings of the National Academy of Science USA, 95, 14843-14847.

Hemsley-Flint, B. (2000) classification of the biological quality of rivers in England and Wales. In Assessing the biological quality of fresh waters: RIVPACS and other techniques (ed. J. F. Wright, D. W. Sutcliffe \& M. T. Furse), pp. 55-69. Ambleside, UK: Freshwater Biological Association.

Hering D., Johnson R. K., Kramm S., Schmutz S., Szoszkiewicz K. \& Verdonschot P. F. M. (2006) Assessment of European streams with diatoms, macrophytes, macroinvertebrates and fish: a comparative metric-based analysis of organism response to stress. Freshwater Biology, 51, 1757-1785. 
Hering D., Verdonschot P. F. M., Moog O. \& Sandin L. (ed.) (2004) Integrated assessment of running waters in Europe. Developments in Hydrobiology 175 (reprinted from Hydrobiologia 516).

Höskuldsson A. (1988) PLS regression methods. Journal of Chemometrics, 2, 211-228.

Hughes R. M. \& Larsen D. P. (1988) Ecoregions: an approach to surface water protection. Journal Water Pollution Control Federation, 60, 486-493.

Illies J. (ed.) (1978) Limnofauna Europaea. A checklist of the animals inhabiting european Inland Waters, with accounts of their distribution and ecology (except protozoa). Stuttgart: Gustav Fisher Verlag.

Johnson T. E., McNair J. N., Srivastava P. \& Hart D. D. (2007) Stream ecosystem responses to spatially variable land cover: an empirically based model for developing riparian restoration strategies. Freshwater Biology, 52, 680-695.

Lammert M. \& Allan J. D. (1999) Assessing biotic integrity of streams: Effects of scale in measuring the influence of land use/cover and habitat structure on fish and macroinvertebrates. Environmental Management, 23, 257-270.

Maridet L., Wasson J. G., Philippe M., Amoros C. \& Naiman R. J. (1998) Trophic structure of three streams with contrasting riparian vegetation and geomorphology. Archiv für Hydrobiologie, 144, 61-85.

Martens H. \& Martens M. (2000) Modified jack-knife estimation of parameter uncertainty in bilinear modelling (PLSR). Food Quality and Preference, 11, 5-16.

Meador M. R. \& Goldstein R. M. (2003) Assessing water quality at large geographic scales: Relations among land use, water physicochemistry, riparian condition, and fish community structure. Environmental Management, 31, 504-517.

Meiner A. (1999) Implementation of CORINE Land Cover project in Estonia. Land cover of Estonia. Tallinn.

Moore A. A. \& Palmer M. A. (2005) Invertebrate biodiversity in agricultural and urban headwater streams: implications for conservation and management. Ecological Applications, 15, 1169-1177.

Naiman R. J., Décamps H. \& McClain M. (2005) Riparia. Ecology, conservation, and management of streamside communities: Academic Press.

Naiman R. J., Lonzarich D. G., Beechie T. J. \& Ralph S. C. (1992) General principles of classification and the assessment of conservation potential in rivers. In Rivers Conservation and Management (ed. P. Boon, P. Calow \& G. Petts), pp. 93-123. Chichester, UK: Wiley \& Sons. 
Olsauskyke V. \& Van de Bund W. (ed.) (2008) WFD intercalibration technical report, Part 1 Rivers, Section 2 Benthic macroinvertebrates. Ispra: Joint Research Centre. (available from http://circa.europa.eu/Public/irc/jrc/jrc_eewai/library)

Omernik J. M. (1987) Ecoregions of the conterminous United States. Annals of the Association of American Geographers, 77, 118-125.

Omernik J. M. (2004) Perspectives on the nature and definition of ecological regions. Environmental Management, 34, S27-S38.

Palmer M. A., Bernhardt E. S., Hassett B., Allan J. D., Alexander G., Lake P. S., Brooks S., Carr J., Hart D. D., Clayton S., Goodwin P., Dahm C. N., Follstad Shah J., Galat D. L., O'Donnell T. K., Loss S. G., Jenkinson R., Kondolf G. M., Lave R., Pagano L., Meyer J. L. \& Sudduth E. (2005) Standards for ecologically successful river restoration. Journal of Applied Ecology, 42, 208.

Paul M.J. \& Meyer J.L. (2001) Streams in the urban landscape. Annual Review of Ecology and Systematics, 32, 333-365.

Pella H., Chandesris A. \& Wasson J. G. (2004) Constitution d'un système d'information à référence spatiale dans le contexte de la Directive Cadre européenne sur l'eau. Ingénieries - Eau Agriculture Territoires, 40, 11-20.

Pont D., Hugueny B., Beier B., Goffaux D., Melcher A., Noble R., Rogers C., Roset N. \& Schmutz S. (2006) Assessing river biotic condition at a continental scale: a European approach using functional metrics and fish assemblages. Journal of Applied Ecology, 73, 70-80.

REFCOND (2003) Rivers and lakes - typology, reference conditions and classification systems. Common Implementation Strategy for the Water Framework Directive (2000/60/ec), Guidance Document no 10. Luxembourg: Office for Official Publications of the European Communities.

Roth N. E., Allan J. D. \& Erickson D. L. (1996) Landscape influences on stream biotic integrity assessed at multiple spatial scales. Landscape Ecology, 11, 141-156.

Roy A. H., Rosemond A. D., Paul M. J., Leigh D. S. \& Wallace J. B. (2003) Stream macroinvertebrate response to catchment urbanisation (Georgia, USA). Freshwater Biology, 48, 329-346.

Skinner J. A., Lewis K. A., Bardon K. S., Tucker P., Catt J. A. \& Chambers B. J. (1997) An overview of the environmental impact of agriculture in the U.K. Journal of Environmental Management, 50, 111-128. 


\section{Sokal R. R., Rohlf, F. J. (1995) Biometry. The principles and practice of statistics in}

\section{biological research. New York: W. H. Freeman and company.}

Sponseller R. A., Benfield E. F. \& Valett H. M. (2001) Relationships between land use, spatial scale and stream macroinvertebrate communities. Freshwater Biology, 46, 1409-1424.

Steedman R. J. (1988) Modification and assessment of an index of biotic integrity to quantify stream quality in Southern Ontario. Canadian Journal of Fisheries and Aquatic Sciences, 45, 492-501.

Stepenuck K. F., Crunkilton R. L. \& Wang L. Z. (2002) Impacts of urban landuse on macroinvertebrate communities in southeastern Wisconsin streams. Journal of the American Water Resources Association, 38, 1041-1051.

Stewart J. S., Wang L., Lyons J., Horwatich J. A. \& Bannerman R. (2001) Influences of watershed riparian-corridor, and reach-scale characteristics on aquatic biota in agricultural watersheds. Journal of the American Water Resources Association, 37, $1475-1487$.

Tenenhaus M. (1998) La regression PLS. Paris: Technip.

Tenenhaus M., Gauchi J. P. \& Menardo C. (1995) Régression PLS et applications. Revue de Statistique Appliquée, 43, 7-63.

Tormos T., Kosuth P., Durrieu S., Wasson J. G., Pella H. \& Villeneuve B. (2006) Contribution of remote sensing for the spatial analysis of land use in river corridors to model relationship between land use pressures and the ecological status of rivers. In Man and River Systems - Interactions among Rivers, their Watersheds, and the Sociosystem (ed. PIREN-Seine), pp. 249-252. Paris.

Verdonschot P. F. M. \& Nijboer R. C. (2004) Testing the European stream typology of the Water Framework Directive for macroinvertebrates. Hydrobiologia, 516, 35-54.

Walser C. A. \& Bart H. L. (1999) Influence of agriculture on in-stream habitat and fish community structure in Piedmont watersheds of the Chattahoochee River System. Ecology of Freshwater Fish, 8, 237-246.

Walsh C. J., Waller K. A., Gehling J. \& Mac Nally R. (2007) Riverine invertebrate assemblages are degraded more by catchment urbanisation than by riparian deforestation. Freshwater Biology, 52, 574-587.

Wang L. \& Kanehl P. (2003) Influences of watershed urbanization and instream habitat on macroinvertebrates in cold water streams. Journal of the American Water Resources Association, 35, 1181-1196. 
Wang L., Lyons J. \& Kanehl P. (2001) Impacts of urbanization on stream habitat and fish across multiple spatial scales. Environmental Management, 28, 255-266.

Wang L., Lyons J., Kanehl P., Bannerman R. \& Emmons E. (2000) Watershed urbanization and changes in fish communities in southeastern Wisconsin streams. Journal of the American Water Resources Association, 36, 1173-1189.

Warry N. D. \& Hanau M. (1993) The use of terrestrial ecoregions as a regional-scale screen for selecting representative reference sites for water quality monitoring. Environmental Management, 17, 267-276.

Wasson J. G. (1996) Structures régionales du bassin de la Loire. La Houille Blanche, 6/7, 2531.

Wasson J. G., Barrera S., Barrère B., Binet D., Collomb D., Gonzales I., Gourdin F., Guyot J. L. \& Rocabado G. (2002a) Hydro-ecoregions of the Bolivian Amazon: a geographical framework for the functioning of river ecosystems. In The Ecohydrology of South American Rivers and Wetlands, vol. Special publication nº6, Chap. 5 (ed. M. E. McClain), pp. 69-91. Wallingford: International Association of Hydrological Sciences (IAHS) Press.

Wasson J. G., Chandesris A., Garcia A., Pella H. \& Villeneuve B. (2007) Relationships between ecological and chemical status of surface waters. European HydroEcoregions, pp. 43: Cemagref Lyon UR BEA/LHQ.

Wasson J. G., Chandesris A., Pella H. \& Blanc L. (2002b) Les hydro-écorégions de France métropolitaine. Approche régionale de la typologie des eaux courantes et éléments pour la définition des peuplements de référence d'invertébrés, pp. 190: Cemagref Lyon UR BEA/LHQ.

Wasson J. G., Chandesris A., Pella H. \& Blanc L. (2002c) Typology and reference conditions for surface water bodies in France: the hydro-ecoregion approach. TemaNord, 566, 3741.

Wasson J. G., Villeneuve B., Mengin N., Pella H. \& Chandesris A. (2005) Modèles pressions / impacts. Approche méthodologique, modèles d'extrapolation spatiale et modèles de diagnostic de l'état écologique basés sur les invertébrés en rivière (IBGN), pp. 61 p + annexes: Cemagref Lyon UR BEA/LHQ.

Wold H. (1982) Soft modelling. The basic design and some extensions. In Systems Under Indirect Observation, vol. I and II (ed. K.-G. Jöreskog \& H. Wold). Amsterdam. Wold S. (1966) Estimation of principal components and related models by iterative least squares. Multivariate analysis. New York: Academic Press. 
Wold S., Sjöström M. \& Eriksson L. (2001) PLS regression: a basic tool of chemometrics. Chemometrics and Intelligent Laboratory Systems, 58, 109-130.

Wright J. F., Sutcliffe D. W. \& Furse M. T. (2000) Assessing the biological quality of freshwaters: RIVPACS and other techniques. Ambleside (UK): Freshwater Biological Association.

Zelinka M. \& Marvan P. (1986) Saprobní index, jeho varianty a možnosti použití. Sb.

Biologické hodnocení jakosti povrchových vod. Metodický pokyn MLVH ČSR, 50, 1937. 
Table 1 General characteristics of the regions used in the analyses: Hydro-ecoregion (HER), Geology-relief and Climate

\begin{tabular}{|c|c|c|c|}
\hline Region & HER name & Geology- Relief & Climate \\
\hline \multicolumn{4}{|l|}{ France } \\
\hline Armorican & BRETAGNE NORMANDIE & Siliceous lowlands & oceanic \\
\hline Armorican & MASSIF ARMORICAIN CENTRAL & Siliceous lowlands & temperate \\
\hline Tables Calcaires & FRENCH TABLES CALCAIRES & Tabular calcareous & temperate \\
\hline Massif Central & FRENCH MASSIF CENTRAL SOUTH & Siliceous mid-alt. mountain & temperate \\
\hline Massif Central & FRENCH MASSIF CENTRAL NORTH & Siliceous hills & temperate \\
\hline Mediterranean & LANGUEDOC & Alluvial plain & mediterranean \\
\hline Mediterranean & PROVENCE & Heterogeneous relief & mediterranean \\
\hline \multicolumn{4}{|l|}{ Slovakia } \\
\hline Carpathians & INNER CARPATHIANS & Siliceous mid-alt. mountain & alpine \\
\hline Carpathians & OUTER CARPATHIANS & Sedimentary mid-alt. mountain & alpine \\
\hline Pannonians & PANNONIAN PLAIN & Clayed plains & temperate warm \\
\hline Pannonians & PANNONIAN FOOTHILLS & Detritic hills & temperate warm \\
\hline Pannonians & TRANSDANUBIAN HILLS & Calcareous hills & temperate warm \\
\hline \multicolumn{4}{|l|}{ Estonia } \\
\hline Estonia & BALTIC PLAIN & Clayed plains & continental cold \\
\hline \multicolumn{4}{|l|}{$U K$} \\
\hline English Uplands & ENGLISH UPLANDS & Calcareous hills & oceanic \\
\hline Cornwall and Wales & WALES & Siliceous hills & oceanic \\
\hline Cornwall and Wales & CORNWALL & Siliceous lowlands & oceanic \\
\hline English Chalk & ENGLISH CHALK & Tabular calcareous & temperate \\
\hline English Sedimentary & ENGLISH SEDIMENTARY & Tabular calcareous & temperate \\
\hline
\end{tabular}


Table 2 Description of land cover (from CORINE Land Cover 2000) of the regions used in the analyses. For each region, the percentage cover of urbanized (CLC1), arable land (CLC 211), other high pressure agriculture, pastures (CLC 231), other low pressure agriculture, forest (CLC 311 , 312, 313), natural (other CLC 3), wetlands and water (CLC 4 and CLC 5).

\begin{tabular}{|c|c|c|c|c|c|c|c|c|c|}
\hline Country & Region & Urbanized & Arable land & $\begin{array}{l}\text { Other high } \\
\text { pressure } \\
\text { agriculture }\end{array}$ & Pastures & $\begin{array}{l}\text { Other low } \\
\text { pressure } \\
\text { agriculture }\end{array}$ & Forests & $\begin{array}{c}\text { Natural } \\
\text { areas }\end{array}$ & $\begin{array}{l}\text { Wetlands } \\
\text { and water }\end{array}$ \\
\hline France & Armorican & 4,8 & 33,6 & 24,3 & 25,1 & 1,8 & 7,7 & 1,1 & 1,6 \\
\hline France & Tables Calcaires & 5,9 & 55,2 & 5,7 & 13,6 & 1,6 & 16,4 & 0,7 & 0,8 \\
\hline France & Massif Central & 2,3 & 6,5 & 15,1 & 34,9 & 3,8 & 32,5 & 4,5 & 0,5 \\
\hline France & Mediterranean & 8 & 5,6 & 34,7 & 0,4 & 3,3 & 25 & 18 & 4,9 \\
\hline Slovakia & Carpathians & 4,3 & 17,6 & 1,1 & 8,2 & 9,1 & 53,3 & 5,9 & 0,4 \\
\hline Slovakia & Pannonians & 7,4 & 65,9 & 2,2 & 1,9 & 4,9 & 14,8 & 1,5 & 1,4 \\
\hline Estonia & Estonia & 1,9 & 15 & 3,9 & 5,7 & 7,9 & 46,1 & 9,5 & 10 \\
\hline UK & Cornwall and Wales & 4,1 & 5,4 & 7,6 & 47,5 & 3,6 & 8,9 & 20,7 & 2,3 \\
\hline UK & English Uplands & 8,7 & 11,3 & 2,6 & 44 & 1 & 6 & 21,8 & 4,6 \\
\hline UK & English Sedimentary & 12,1 & 55,1 & 4,9 & 20,9 & 1,3 & 3,2 & 1,2 & 1,3 \\
\hline UK & English Chalk & 14,2 & 63,1 & 2,5 & 8,8 & 1,9 & 6 & 1,2 & 2,3 \\
\hline
\end{tabular}


Table 3 Results of the PLS regression for France: national model (France-all), and Armorican, Tables Calcaires, Massif Central and Mediterranean regions. Standardized PLS regression coefficients between EQR-IBGN and significant land cover variables (from CORINE Land Cover 2000) at both basin and riparian scales. Negative coefficients in bold characters and positive coefficients in italics. $\mathrm{R}^{2}$ : coefficient of determination of the models.

\begin{tabular}{|c|c|c|c|c|c|c|c|c|c|c|c|}
\hline \multirow[b]{3}{*}{ CLC code } & \multirow[t]{2}{*}{ France } & \multicolumn{2}{|c|}{$\begin{array}{c}\text { France - all } \\
(n=3662)\end{array}$} & \multicolumn{2}{|c|}{$\begin{array}{c}\text { Armorican } \\
(n=116)\end{array}$} & \multicolumn{2}{|c|}{$\begin{array}{c}\text { Tables Calcaires } \\
(n=378)\end{array}$} & \multicolumn{2}{|c|}{$\begin{array}{c}\text { Massif Central } \\
(n=458)\end{array}$} & \multicolumn{2}{|c|}{$\begin{array}{c}\text { Mediterranean } \\
\quad(n=182)\end{array}$} \\
\hline & & \multicolumn{2}{|c|}{$R^{2}=18 \%$} & \multicolumn{2}{|c|}{$\mathbf{R}^{2}=20 \%$} & \multicolumn{2}{|c|}{$R^{2}=15 \%$} & \multicolumn{2}{|c|}{$\mathbf{R}^{2}=31 \%$} & \multicolumn{2}{|c|}{$\mathbf{R}^{2}=38 \%$} \\
\hline & CLC name & basin & riparian & basin & riparian & basin & riparian & basin & riparian & Basin & riparian \\
\hline 111 & Continuous urban fabric & -0.09 & & -0.07 & & -0.07 & & -0.13 & & -0.12 & -0.05 \\
\hline 112 & Discontinuous urban fabric & -0.16 & -0.08 & -0.19 & -0.09 & -0.18 & -0.09 & -0.18 & -0.12 & -0.21 & -0.07 \\
\hline 121 & Industrial-commercial units & -0.10 & -0.09 & -0.12 & & -0.10 & & -0.16 & -0.15 & -0.16 & \\
\hline 132 & Dump sites & -0.04 & & & & & & & & & \\
\hline 133 & Construction sites & -0.04 & & & & & & & & & \\
\hline 211 & Non irrigated arable land & -0.07 & -0.05 & -0.09 & & & & & & & \\
\hline 221 & Vineyards & -0.06 & & -0.07 & & & & -0.09 & -0.08 & & \\
\hline 222 & Fruit trees & -0.04 & & -0.04 & -0.03 & & & & & -0.11 & \\
\hline 231 & Pastures & & & & & 0.06 & 0.10 & & & 0.10 & 0.06 \\
\hline 311 & Broad-leaved forest & 0.05 & 0.05 & 0.11 & 0.11 & & & & & 0.12 & \\
\hline 312 & Coniferous forest & 0.07 & & & & & & 0.10 & 0.08 & & \\
\hline 313 & Mixed forest & 0.05 & & & & & & & & 0.08 & \\
\hline 322 & Moors and heathland & & & & & & & & & 0.07 & \\
\hline 333 & Sparsely vegetated areas & 0.04 & & & & & & & & & \\
\hline
\end{tabular}


Table 4 Results of the PLS regression for Slovakia: national model (Slovakia-all), and Carpathians and Pannonians regions. Standardized PLS regression coefficients between EQR-SI and significant land cover variables (from CORINE Land Cover 2000) at both basin and riparian scale. Negative coefficients in bold characters and positive coefficients in italics. $\mathrm{R}^{2}$ : coefficient of determination of the models.

\begin{tabular}{|c|c|c|c|c|c|c|c|}
\hline \multirow[b]{3}{*}{ CLC code } & \multirow{3}{*}{$\begin{array}{l}\text { Slovakia } \\
\text { CLC name } \\
\end{array}$} & \multirow{2}{*}{\multicolumn{2}{|c|}{$\begin{array}{c}\begin{array}{c}\text { Slovakia }- \text { all } \\
(n=193)\end{array} \\
\mathbf{R}^{\mathbf{2}}=\mathbf{4 4} \%\end{array}$}} & \multirow{2}{*}{\multicolumn{2}{|c|}{$\begin{array}{c}\begin{array}{c}\text { Carpathians } \\
(n=137)\end{array} \\
\mathbf{R}^{\mathbf{2}}=\mathbf{3 8} \% \\
\end{array}$}} & \multirow{2}{*}{\multicolumn{2}{|c|}{$\begin{array}{c}\begin{array}{c}\text { Pannonians } \\
(n=56)\end{array} \\
\mathbf{R}^{2}=\mathbf{2 9} \%\end{array}$}} \\
\hline & & & & & & & \\
\hline & & basin & riparian & basin & riparian & basin & riparian \\
\hline 1 & Artificial surfaces & $-0,17$ & & $-0,15$ & & $-0,24$ & \\
\hline 2 & Agricultural areas & $-0,17$ & & $-0,16$ & & $-0,14$ & \\
\hline 3 & Forests and semi-natural areas & 0,18 & & 0,17 & & 0,17 & \\
\hline 121 & Industrial-commercial units & & $-0,07$ & & $-0,09$ & & \\
\hline 211 & Non irrigated arable land & & $-0,11$ & & $-0,09$ & & \\
\hline 311 & Broad-leaved forest & & 0,08 & & 0,07 & & 0,14 \\
\hline 312 & Coniferous forest & & 0,12 & & 0,13 & & \\
\hline 313 & Mixed forest & & 0,06 & & 0,07 & & \\
\hline
\end{tabular}


Table 5 Results of the PLS regression for Estonia. Standardized PLS regression coefficients between EQR-ASPT and significant land cover variables (from CORINE Land Cover 2000) at both basin and riparian scale. Negative coefficients in bold characters and positive coefficients in italics. $\mathrm{R}^{2}$ : coefficient of determination of the model.

\begin{tabular}{clcc}
\hline & \multicolumn{1}{c}{ Estonia } & \multicolumn{2}{c}{$\begin{array}{c}\text { Estonia }- \text { all } \\
(n=168)\end{array}$} \\
\hline & & \multicolumn{2}{c}{$\mathbf{R}^{\mathbf{2}=\mathbf{3 9} \%}$} \\
\hline CLC code & \multicolumn{1}{c}{ CLC name } & basin & riparian \\
\hline 112 & Discontinuous urban fabric & $\mathbf{- 0 , 2 4}$ & $\mathbf{- 0 , 0 9}$ \\
121 & Industrial-commercial units & $\mathbf{- 0 , 2 8}$ & \\
211 & Non irrigated arable land & $\mathbf{- 0 , 1 3}$ & \\
312 & Coniferous forest & & 0,08 \\
313 & Mixed forest & 0,15 & \\
321 & Natural grassland & $\mathbf{- 0 , 1 0}$ & \\
512 & Water bodies & 0,09 & \\
\hline
\end{tabular}


Table 6 Results of the PLS regression for UK: national model (UK-all), and English Uplands, Cornwall and Wales, English Sedimentary and English Chalk regions. Standardized PLS regression coefficients between EQI-N-Taxa or EQI-ASPT and significant land cover variables (from Land Cover Map 2000) at basin scale. Negative coefficients in bold characters and positive coefficients in italics. $\mathrm{R}^{2}$ : coefficient of determination of the models.

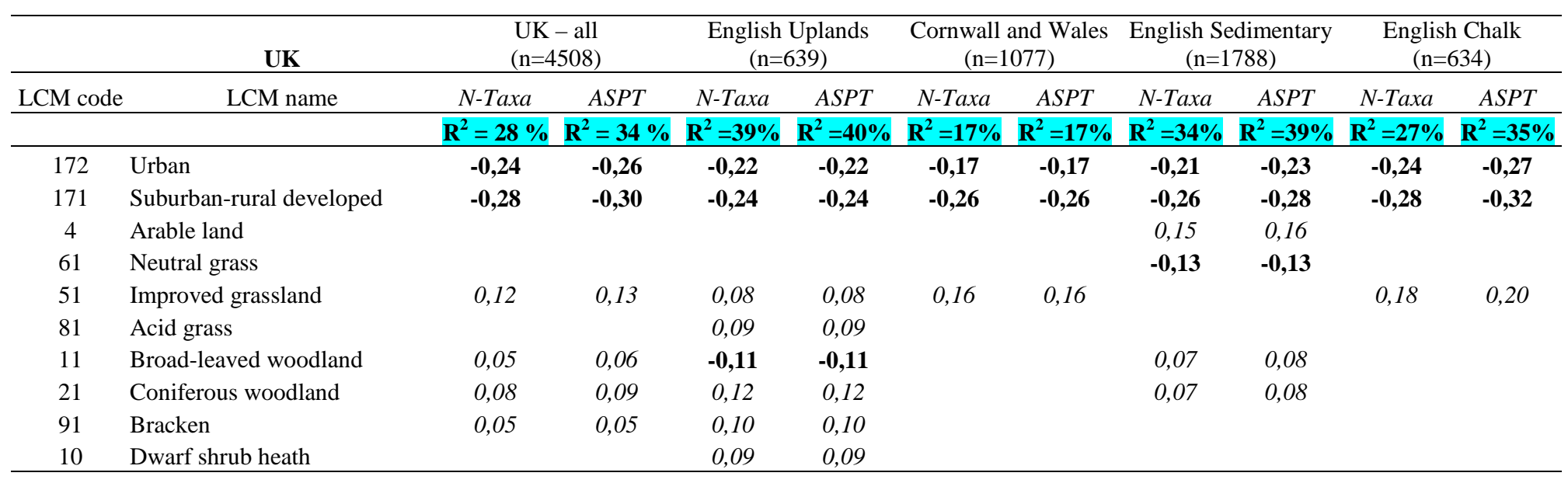


Table 7 Test of the effect of agricultural land cover independent of its correlation with the percentage of urban land cover within the basins for each region of France, Slovakia, Estonia and United Kingdom. Pearson's correlation between urban and agricultural land cover in the basins; linear regression between EQR (or EQI) and urban land cover; multiple linear regression (MLR) between EQR (or EQI) and urban + agricultural land cover; difference in $\mathrm{R}^{2}$ of the two regressions and extra sum of square F-test p-value between both models.

\begin{tabular}{ccccccc}
\hline Country & Region & $\begin{array}{c}\text { Pearson's correlation } \\
\text { urban / agricultural } \\
\text { land cover }\end{array}$ & $\begin{array}{c}\text { Linear } \\
\text { regression EQR } \\
\text { f f(urban) }\end{array}$ & $\begin{array}{c}\text { Multiple Linear } \\
\text { regression } \\
\text { EQR } \\
\text { f(urban+agricultural) }\end{array}$ & Difference & $\begin{array}{c}\text { Extra sum of } \\
\text { square F-test }\end{array}$ \\
\hline France & Armorican & 0.035 & $14.7 \%$ & $14.7 \%$ & $0.0 \%$ & 0.86 \\
France & Tables Calcaires & -0.076 & $12.7 \%$ & $14.2 \%$ & $1.5 \%$ & $\mathbf{0 . 0 1}$ \\
France & Massif Central & -0.092 & $21.0 \%$ & $22.0 \%$ & $1.0 \%$ & $\mathbf{0 . 0 0 9}$ \\
France & Mediterranean & -0.1 & $33.0 \%$ & $33.6 \%$ & $0.6 \%$ & 0.54 \\
Slovakia & Carpathians & 0.56 & $23.0 \%$ & $31.7 \%$ & $8.7 \%$ & $<\mathbf{0 . 0 0 1}$ \\
Slovakia & Pannonians & 0.53 & $32.0 \%$ & $32.5 \%$ & $0.5 \%$ & 0.67 \\
Estonia & Estonia & 0.06 & $26.0 \%$ & $30.5 \%$ & $4.5 \%$ & $\mathbf{0 . 0 0 1}$ \\
UK & Cornwall and Wales & 0.013 & $16.0 \%$ & $16.4 \%$ & $0.4 \%$ & $\mathbf{0 . 0 0 3}$ \\
UK & English Uplands & -0.03 & $37.0 \%$ & $38.0 \%$ & $1.0 \%$ & $\mathbf{0 . 0 0 4}$ \\
UK & English Sedimentary & -0.54 & $37.7 \%$ & $37.7 \%$ & $0.0 \%$ & 0.88 \\
UK & English Chalk & -0.74 & $29.0 \%$ & $33.9 \%$ & $4.9 \%$ & $<\mathbf{0 . 0 0 1}$ \\
\hline
\end{tabular}


Table 8 Test of the protective effect of riparian pastures (CLC 231) in basins subject to predominantly "agricultural" or "mixed" (agricultural and urban) pressures, in three regions of France (Armorican, Tables Calcaires, Massif Central). Slope and confidence interval of a linear regression between EQR-IBGN and the percentage of pastures in the riparian corridors. Slopes significantly different from zero are in bold characters.

\begin{tabular}{|c|c|c|c|c|c|}
\hline | & HER & Basins & slope & \multicolumn{2}{|c|}{ Confidence interval (95\%) } \\
\hline 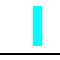 & 1 & 1 & 1 & lower limit & upper limi \\
\hline \multirow{6}{*}{ 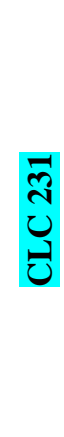 } & Armorican & agricultural & -0.074 & -0.26 & 0.11 \\
\hline & Armorican & mixed & -0.076 & -0.2 & 0.05 \\
\hline & Tables calcaires & agricultural & 0.1 & -0.03 & 0.23 \\
\hline & Tables calcaires & mixed & 0.1 & 0.02 & 0.19 \\
\hline & Massif central & agricultural & -0.09 & -0.25 & 0.06 \\
\hline & Massif central & mixed & 0.15 & 0.01 & 0.29 \\
\hline
\end{tabular}


Table 9 Test of the protective effect of riparian broad-leaved forest (CLC 311) or coniferous forest (CLC 312) in basins subject to predominantly "agricultural" or "mixed" (agricultural and urban) pressures, in three regions of France (Armorican, Tables Calcaires, Massif Central). Slope and confidence interval of a linear regression between EQR-IBGN and the percentage of forest in the riparian corridors. Slopes significantly different from zero are in bold characters.

\begin{tabular}{|c|c|c|c|c|c|}
\hline | & HER & Basins & slope & \multicolumn{2}{|c|}{ Confidence interval (95\%) } \\
\hline 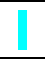 & 1 & 1 & 1 & lower limit & upper limi \\
\hline \multirow{6}{*}{$\begin{array}{l}\bar{m} \\
\text { 己े } \\
\end{array}$} & Armorican & agricultural & 0.12 & -0.08 & 0.3 \\
\hline & Armorican & mixed & 0.3 & 0.08 & 0.47 \\
\hline & Tables calcaires & agricultural & 0.16 & -0.03 & 0.48 \\
\hline & Tables calcaires & mixed & 0.003 & -0.09 & 0.09 \\
\hline & Massif Central & agricultural & 0.23 & 0.05 & 0.41 \\
\hline & Massif Central & mixed & 0.13 & -0.04 & 0.3 \\
\hline \multirow{2}{*}{ 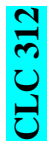 } & Massif Central & agricultural & 0.57 & -0.37 & 1.52 \\
\hline & Massif Central & mixed & 0.49 & 0.08 & 0.9 \\
\hline
\end{tabular}


Table 10 Test of the protective effect of riparian pastures (CLC 231) combined with broadleaved forest (CLC 311) and/or coniferous forest (CLC 312) in basins subject to predominantly "agricultural" or "mixed" (agricultural and urban) pressures, in three regions of France (Armorican, Tables Calcaires, Massif Central). Slope and confidence interval of a linear regression between EQR-IBGN and the percentage of protective land cover categories in the riparian corridors. Slopes significantly different from zero are in bold characters.

\begin{tabular}{|c|c|c|c|c|c|}
\hline I & HER & Basins & slope & \multicolumn{2}{|c|}{ Confidence interval (95\%) } \\
\hline 1 & 1 & 1 & 1 & lower limit & upper limit \\
\hline \multirow{6}{*}{ 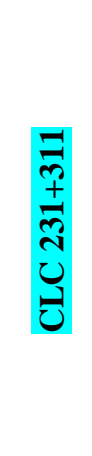 } & Armorican & agricultural & 0.03 & -0.21 & 0.28 \\
\hline & Armorican & mixed & -0.04 & -0.09 & 0.16 \\
\hline & Tables calcaires & agricultural & 0.2 & 0.06 & 0.35 \\
\hline & Tables calcaires & mixed & 0.11 & 0.02 & 0.2 \\
\hline & Massif Central & agricultural & 0.11 & -0.07 & 0.29 \\
\hline & Massif Central & mixed & 0.23 & 0.09 & 0.37 \\
\hline \multirow{2}{*}{ ن } & Massif Central & agricultural & -0.08 & -0.24 & 0.08 \\
\hline & Massif Central & mixed & 0.19 & 0.05 & 0.32 \\
\hline
\end{tabular}

